\title{
Components of grazing behaviour of 3 breeds of heifers
}

\author{
P D'Hour, M Petit, JP Garel
}

\author{
INRA, LAHM, Theix, 63122 St-Genès-Champanelle, France
}

Differences in weight gain at pasture between heifers of different breeds could be explained by variations in components of ingestive behaviour (Erlinger et al, 1990, J Anim Sci, 68, 3578-3587). The aim of this study was to compare the grazing behaviour of heifers belonging to Holstein dairy, Limousine beef and Salers hardy breeds, grazing under 2 sward conditions.

Eight Holstein (HO), 8 Salers (SA) and 8 Limousine (LI) heifers, aged between 14 and 16 months and weighing 413,380 and $346 \mathrm{~kg}$ respectively, grazed together and successively 2 paddocks ( 8 days/pad) of mountainous natural grassland (altitude $1100 \mathrm{~m}$ ) composed mainly of graminae (Agrostis tenuis, Lolium perenne, Dactylis glomerata). The first paddock was at a vegetative (VEG) stage, the second at a reproductive (REP) stage. Measurements were taken throughout the 1st, 4 th and 8th days of the total time spent in paddocks. Grazing time was estimated, from dawn $(5 \mathrm{~h})$ to dusk ( $23 \mathrm{~h}$ ), by observing the activity of each heifer (head down to ground) at 5 minute intervals. Individual bite rates were measured each day, 10 to 15 times for each heifer : the number of bites taken in 2 minutes was counted and related to the corresponding grazing time. Sward height varied between the beginning and end of time spent in paddocks, from 34 to $11.5 \mathrm{~cm}$ for the VEG and from 39 to $8 \mathrm{~cm}$ for REP stage. Herbage quantity varied from 4.5 to $2.4 \mathrm{t}$ of $\mathrm{DM} / \mathrm{ha}$ and from 6.6 to $2.5 \mathrm{t}$ of $\mathrm{DM} /$ ha respectively.

During time spent in paddocks, bite rate decreased $(P<0.001)$ from 56.4 to 48.5 bites/min (VEG) and from 31.4 to 27.4 bites/min (REP). Grazing time increased $(P<0.001)$ in the first case (290 to $438 \mathrm{~min}$ ) and decreased $(P<0.001)$ in the second $(533$ to $396 \mathrm{~min}$ ). From the VEG to the REP stage grazing time increased $(P<0.001)$ from 354 to $485 \mathrm{~min}$, whereas bite rate decreased $(\mathrm{P}<0.001)$ from 52.7 to 29.5 bites $/ \mathrm{min}$. For both stages, SA heifers grazed 20 to $30 \mathrm{~min}$ less $(P<0.001)$ than $\mathrm{LI}$ and $\mathrm{HO}$ which showed the same grazing time. Bite rate was, regardless to grass stage, higher $(P<0.01)$ for $\mathrm{HO}$ and SA than for $\mathrm{LI}$; for REP grass it was slightly higher $(P<0.001)$ for $S A$ than for $H O$. The number of bites taken throughout the day on VEG grass was higher $(\mathrm{P}<0.001)$ for $\mathrm{HO}$ than for SA heifers, which in turn was higher $(P<0.001)$ than for LI. On REP grass, $\mathrm{HO}$ and SA heifers showed a similar number of bites, far greater $(P<0.001)$ than that taken by $L I$. From VEG to REP grass, the number of bites tended to decrease less $(P<0.1)$ for $S A$ than for $\mathrm{LI}$ or $\mathrm{HO}$.

Finally, on VEG grass, heifers of the 3 breeds $\mathrm{HO}, \mathrm{SA}$ and $\mathrm{LI}$ were classified, for number of bites, in the same order as for their indoor intake capacity (Agabriel et al, 1987, Reprod Nutr Dev, 27, 1B, 211-212). For both grasses, $S A$ took a greater number of bites than LI showing a shorter grazing time and a higher bite rate ; these differences could be linked to weight (Funston et al, 1991, J Anim Sci, 69, 1435-1442) and/or to a greater selectivity of LI. Determination of bite weight would allow confirmation or invalidation of these behavioural differences in terms of herbage intake.

\section{Grass stage}

Breed

Grazing time (min/day)

Biting rate (bites/min)

Daily bites number $\left(x 10^{3}\right)$

\begin{tabular}{cc} 
& \multicolumn{2}{c}{ VEG } \\
\cline { 1 - 1 } SA & LI \\
335 & 362 \\
55.4 & 48.2 \\
18.4 & 17.3
\end{tabular}

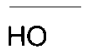

369

54.7

19.9 $\overline{\operatorname{sed}^{*}}$

6.0

0.86

0.46

\begin{tabular}{cccc}
\multicolumn{4}{c}{ REP } \\
\cline { 1 - 1 } SA & LI & HO & sed $^{*}$ \\
469 & 496 & 490 & 5.3 \\
32.3 & 25.9 & 30.2 & 0.60 \\
15.2 & 12.9 & 14.9 & 0.33 \\
& & &
\end{tabular}

* sed : standard error of difference 